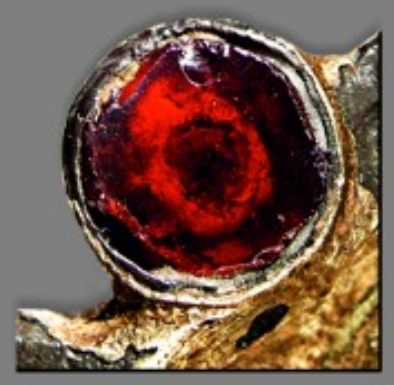

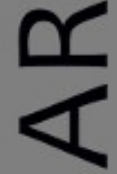

$\sim$

ш
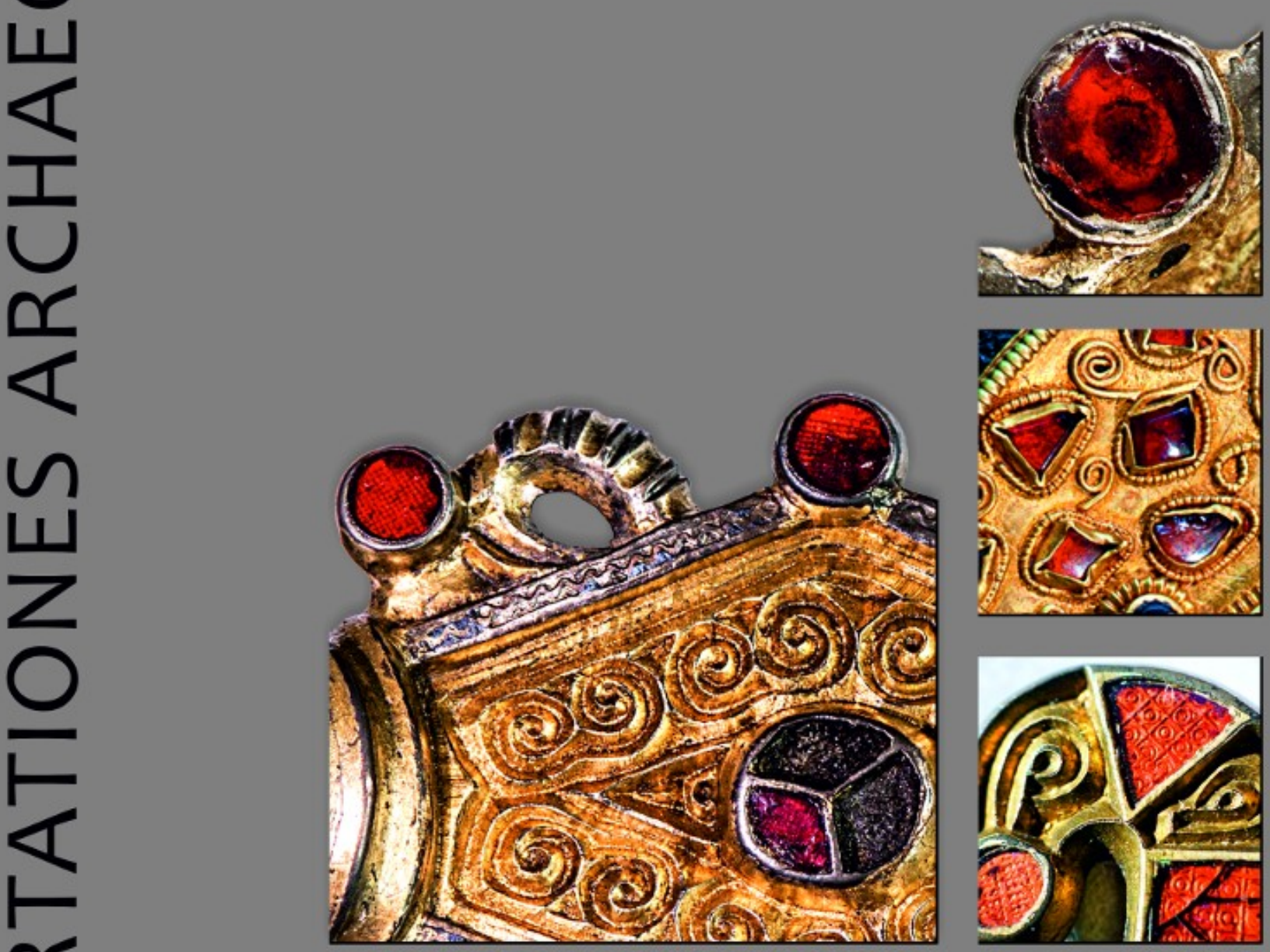

E

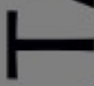

œ

山

n

ก

$\overline{0}$
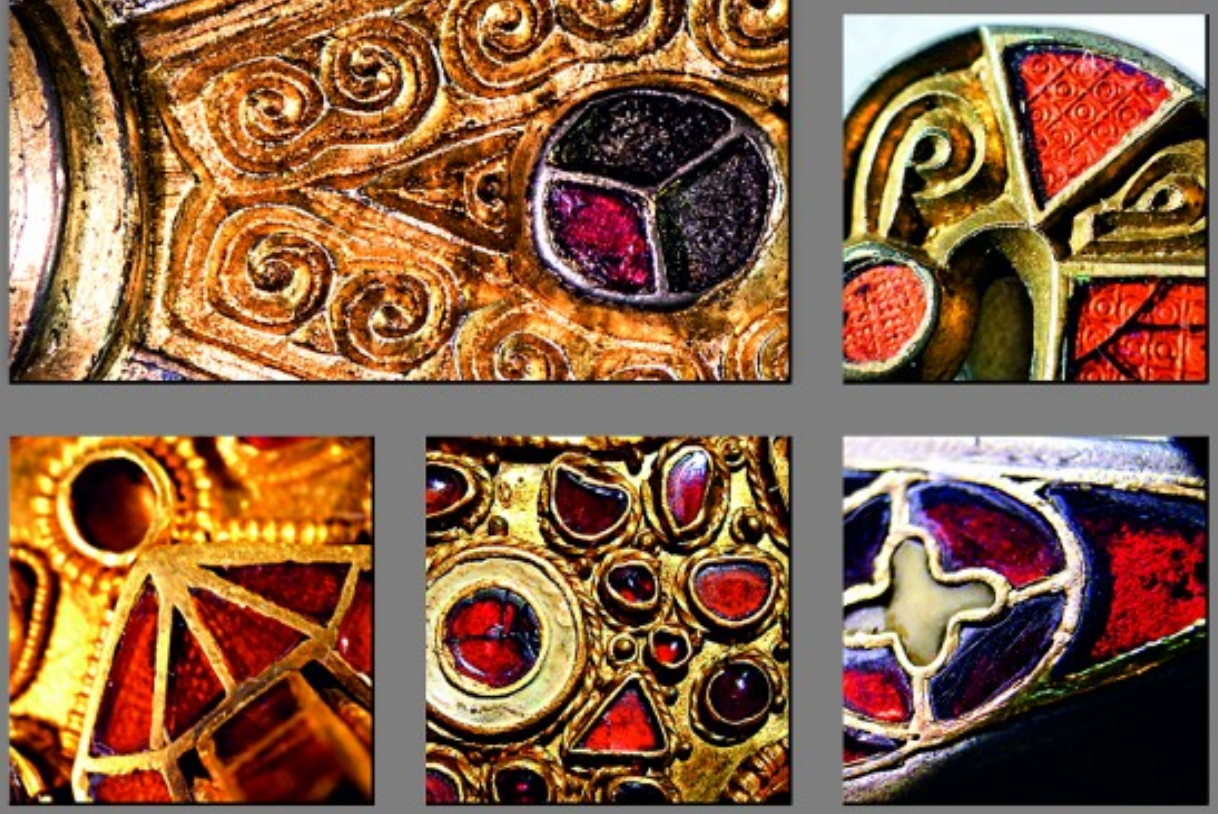

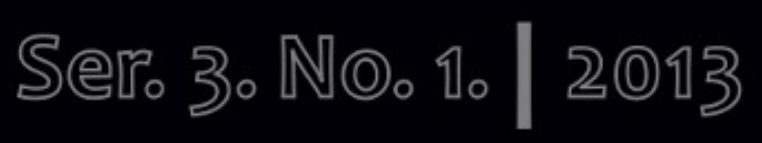




\section{Dissertationes Archaeologicae ex Instituto Archaeologico}

Universitatis de Rolando Eötvös nominatae Ser. 3. No. 1.

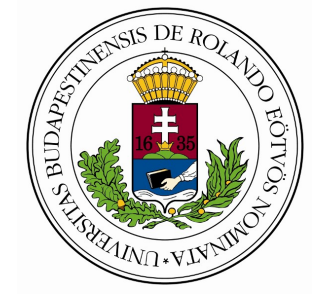

Budapest 2013 
Dissertationes Archaeologicae ex Instituto Archaeologico

Universitatis de Rolando Eötvös nominatae

Ser. 3. No. 1.

Editor-in-chief:

DÁvid BARTUS

Editorial board:

LÁSZLÓ BARTOSIEWICZ

LÁSZLÓ BORHY

ISTVÁN FELD

GÁBOR KALLA

PÁL RACZKY

Miklós SzABÓ

TIVADAR VIDA

Technical editors:

DÁvid BARTuS

GÁBOR VÁCZI

ANDRÁs BöDŐcs

Proofreading:

Zsófia KondÉ

SzILvia SzÖLlősI

Available online at http://dissarch.elte.hu

Contact: dissarch@btk.elte.hu

\section{$\underline{\text { PKP }}$ \\ PUBLIC \\ KNOWLEDGE \\ PROJECT}

(C) Eötvös Loránd University, Institute of Archaeological Sciences

Budapest 2013 


\section{Contents}

\section{Articles}

Melinda TORBÁGYI - István VIDA

The coin hoard of Abasár

Anikó BózsA

21

Roman mirrors from a private collection in the Hungarian National Museum

Lajos JuHÁsz

45

The Biesheim cameo - a reinterpretation

\section{Methods}

Péter CsIPpÁN

$A z$ állatcsont, mint információhordozó leletanyag

Kata DÉvAI

Terminológiai alapfogalmak régészeti korú üvegtárgyak elemzéséhez

Lőrinc TimáR - Zoltán Czajlik - Sándor Puszta - Balázs Holl

$3 D$ reconstructions using GPR data at the Mont Beuvray

\section{FIELD REPORTS}

Zsolt MESTER

Excavation at a new Upper Palaeolithic site of the Eger region (Northern Hungary)

László BORHY - Dávid BARTus - Emese SzÁmadó

Short report on the excavations at Brigetio (Szőny-Vásártér) in 2013

Dénes HulLÁm - Zsófia RÁcz

Report on the participation of the Eötvös Loránd University at the Wielbark Archaeological Field School in Malbork-Wielbark, Poland

Gábor VÁczi - Dávid BARTus

Short report on the excavations at the site Makó - Igási Ugar

Maxim MoRdovin

Short report on the excavations in 2013 of the Department of Hungarian Medieval and Early Modern Archaeology (Eötvös Loránd University, Budapest)

\section{THESIS ABSTRACTS}

Kitti KÖHLER

Biological reconstruction of the Late Neolithic Lengyel Culture 
Cultural connections and interactions of Eastern Transdanubia during the Urnfield period

Orsolya LÁNG

Urban problems in the civil town of Aquincum: the so-called „northern band”

Nikoletta SEY

Questions of bronze workshops in Roman Pannonia

Kata DÉvaI

Glass vessels from Late Roman times found in graves in the Hungarian part of Pannonia

Eszter HORvÁTH

Gemstone and glass inlaid fine metalwork from the Carpathian Basin:

the Hunnic and Early Merovingian Periods

Gergely SzEnTHE

Vegetal ornaments in the Late Avar decorative art

Péter LANGó

Relations between the Carpathian Basin and South East Europe during the 10th century.

The evidence of the minor objects

Ciprián HoRvÁTH

The Cemeteries and Grave Finds of Györ and Moson Counties from the Time

of the Hungarian Conquest and the Early Árpádian Age

András Sófalvi

The border- and self-defence of Szeklers from the Medieval Age till the Age of Principality.

Castles and other defence objects in the settlement history of Udvarhelyszék 


\title{
Relations between the Carpathian Basin and South East Europe during the 1oth century. The evidence of the minor objects
}

PÉTER LANGó

Research Center for the Humanities, Institute of Archaeology

Hungarian Academy of Sciences

lango.peter@btk.mta.hu

\begin{abstract}
PhD thesis submitted in 2013 to the Archaeology Doctoral Programme, Doctoral School of History, Eötvös Loránd University, Budapest under the supervision of Csanád Bálint.
\end{abstract}

\section{Introduction}

One of the most influential neighbours of the Hungarian tribal confederation - sometimes as an ally, sometimes as an enemy - was Byzantium. The empire of Leo and his son Constantine Porphyrogenitus viewed the nomad tribal confederation led by Levedi, then Álmos as an unpleasant Western neighbour that, however could be put to good use in certain circumstances. This fact shaped the relationship between the two. The Hungarians were fighting either as Byzantine allies or as the enemies of the empire, but the objectives in both cases were the very same: either material booty or economic concessions, and the complex relationship between the two territories is faithfully reflected in the archaeological material.

The present work intends to highlight the relationship between the two sides in the light of their material culture. The objects themselves, conveying a vivid picture on the interrelationship cannot be restricted only to the territories of the Hungarian Principality or to Byzantium proper. One has to consider the intermediary zones between and around the political boundaries of the 10th century Principality and the Empire, and also all those territories with which the Hungarians got into contact in the course of their military ventures. These zones often played a decisive role in transmitting the cultural influence of Byzantium, to which they were bound with numerous threads. Regardless of the Bulgarian and Slavic settlements, contemporary Balkans clung to its Late Antique roots and the links between the material culture of Moravia and Byzantium were also well studied by modern scholarship. Byzantine taste was fundamental in shaping not only the attire but all other forms of the cultural language.

The cultural contacts are best reflected in the objects (coins, jewels, elements of attire) recovered from the 10th century cemeteries and for this reason they form the basis on which this thesis is built. Connected to former directions of scholarly research the present work studies individual object types arranged into classified groups. ${ }^{1}$ This method enabled the most comprehensive collecting, grouping and evaluation of individual object types. During this work

1 Ross 1965; Mesterházy 1991; 1992; Григоров 2007; Bosselmann-Ruickbie 2011. 
I tried to draw conclusions on the nature and intensity of 10th century relations between South Eastern Europe and the Carpathian Basin by the spread of individual object types. I also tried to build up an internal periodization for the material, thus refining the chronology of individual object types. Attempt was also made to compare the archaeological source material with the historical one.

\section{The question of byzantine coin finds}

One of the most important archaeological sources of the period is Byzantine coins. Written sources explicitly prove that the Hungarians crossed the boundaries of the Carpathian Basin with full knowledge and use of money. L. Kovács presenting the analysis of the coin finds stressed that coins could have arrived to the Hungarians in several ways. One of the most common routes, also supported by written evidence, was a military campaign. Many sources recall that Hungarians either sold their captives in slave markets, or released them for ransom. This way it is evident that Hungarians took part in long distance trade well before the conquest, which is also illustrated by the campaign against the Macedonians in 936, the role they played in the slave trade of Cherson mentioned by Muslim sources or the appearance of Hungarians in Byzantine territories of the Crimea. As the participation of Hungarians in the trade of other goods than slaves cannot be excluded, it is unlikely that the larger part of the coin finds were melted by their owners. However, coins that were recycled as raw material can have accounted only for a minor part of the inflow of precious metals. ${ }^{2}$

Although there are still many questions concerning the usefulness of coins in dating, the proportions of catalogued coins reflect fairly well the medium-term processes during the 10th century. ${ }^{3}$ Byzantine coins are also a testimony to the integration of the Hungarians into the European network and also to the development of their own commerce. ${ }^{4}$ Coins reflect a similar chronological development pattern to other objects of South Eastern European origin, like Byzantine hanging crosses or buckles. Early contacts were characterised by casualty, while parallel to the appearance of the Byzantine crosses and buckles in the graves from the second third of the 10th century a much more stable and complex relationship is reflected by the coin finds. This pattern is also reflected in the written records and has its parallel in the Byzantine relations of the Saltovo culture. ${ }^{5}$ The strengthening of the Byzantine contacts with the Steppe are preserved in the written sources as well, and as these contacts waned so did the ratio of the Byzantine or Byzantine influenced objects in the archaeological record.

\section{Earrings and pendants}

The most typical elements of 10th century attire of the Balkans were the earrings and pendants decorating the head of women. One must be cautious however in differentiating between the attire and the objects themselves. Some similar characteristics of attire can appear in different places, regardless of the basic differences of the objects. This can be illustrated by the attire of the rich female burial excavated at Szentes-Derekegyház. ${ }^{6}$ It is also a question 
whether these remains penetrated the Hungarian culture from Byzantine sources directly or were transmitted indirectly, if they were absorbed by the Hungarian culture before the 10th century at all. The finds from Szentes also illustrate that earrings could be used as pendants, while objects explicitly used as pendants are only to be identified with certainty, if their design does not allow their use as earrings. Examples for this can be drawn from the hanging found at Vésztő-Mágor hill and the pendant from grave no. 18 in Örménykút Site 52.

Crescent-shaped earrings with lower ornamental band became fashionable quickly in a relatively widespread area. The basic type of this was formed by the simple earrings grouped into the classification group 1a. Later embellishments formed by enamel inserts could only be afforded by the rich, so the plain forms, sometimes made of simple wires, also remained in fashion. Besides there must have been many regions where the technological knowledge of the production of enamel inserts was simply missing. The golden age of this type of jew ellery was in the second half of the 10th century: at this time the hoards of Crete and Preslav were hidden and this is the period to which the excavated cemeteries are dated. It is very probable, that they appeared in the Carpathian basin at around this period. Analyses of the earrings with a lower arch ornaments and with twisted wire gave birth to many historical hypotheses, but they cannot be used for mapping the movement of different ethnic groups. However they are good indicators for the impact of Byzantine-Balkan influences on the attire of Central-Europe. ${ }^{8}$

Earrings with four large globular pendants appeared in Central Europe in the second half of the 9th century and they were still popular in Czech and Polish territories in the beginning of the 10th century. It also became one of the most appreciated jewellery type of the elite living in the 9th century Byzantine-Moravian-Carolingian border zones. With time its use spread to the regions north of Moravia while it also underwent some modifications. Four globular pendants are known not only from amongst 9th century finds but are also represented in large numbers in the 10th-11th century Carpathian Basin. A considerable part of the 10th century examples are close to the South-Balkan group of Byzantine finds based on their stylistics (the use of double conical shaped globular decoration characteristic of the Southern territories) and their production technique (the large frequency of casting technique). The jewels found in Hungarian settlements were in all probability made in these neighbouring territories or might have originated in Bulgaria. From amongst these objects the earliest example, dated to the first half of the 10th century, was the find of Karos. ${ }^{9}$ Later it was followed by finds from graves datable to the middle third of the 10th century, then by other grave finds from the second half of the century and finally the chronology of the finds seems to close with the group of finds from Gyulafehérvár dated to the first half of the 11th century. ${ }^{10}$

It is likely that the objects found their way to their owners as merchandise, with the exception of the Karos find that might have been a booty item. This hypothesis is also strengthened by its secondary use. 
Prototypes of earrings with grape bunch pendants must also be looked for in Byzantium, and they were already present both in the Carpathian Basin and in the Balkans as early as the 7th century. In early samples there were only a handful of granules soldered to the lower curve of the ring on its outer or inner side, but parallel to this a later development type appeared applying a larger number of granules. This type of earring became a popular piece of jewellery of the 9th century Slavic principalities and the elite of the Carolingian border zones, and their decoration was often enhanced by adding filigree wires to the lower curve. Parallel to the use of precious metal objects - or as a somewhat later development simpler, casted pieces also appeared. A new formal variant of the casted types was introduced in the beginning of the 10th century, but finally it disappeared with all its variants from amongst the 11 th century grave finds. ${ }^{11}$

The inner groups of crescent-shaped earrings with four branches pendant are not only displaying variety in quality, but also show a sharp division with regard to time and space. One group was basically characteristic of the northern part of Central Europe, with only a few examples in South Eastern Europe. At the same time the other group was almost exclusively confined to South East Europe. The presence of this latter group was also characteristic of the material remains of the Hungarian conquerors.

Earrings with lunar ornaments made their appearance in the 9th century in the entire area of the Balkans. The precious metal objects put together from several pieces formed the prototype of which later casted versions also appeared. The multi-piece jewellery however did not disappear with the coming of cast variants; they remained fashionable until the 11th century. The popularity of casted types was the highest in the 10th century. The lunar ornament of finds from Agia Triada and Azoros was widespread in the middle Byzantine period and can be traced back to prototypes from the Late Antique Byzantium, also penetrating the Steppe. ${ }^{12}$ These objects that became popular in the regions south of the Hungarian Principality in the 10th century did not become widespread with the Hungarian population of the conquest, while types that came into existence well before the above mentioned date and thus had time to reach Moravia had an influence on the attire of the Hungarians conquering Moravian territories.

\section{Rings}

Besides earrings, the other outstanding group of small objects in the Byzantine attire are rings. These also formed part of the female attire. Scholarly research identified filigree decorated rings and decorated rings with widening bezel as ones that formed part of the Southern heritage group. According to K. Mesterházy the influx of head compartment rings decorated with filigree and granulation "started in the 9th century (disregarding the early Avar period), but their appearance in large numbers falls to the 10th century." ${ }^{13}$

Decorated rings with widening bezel and rings with rhombic head were collected and analysed by T. Keszi. ${ }^{14}$ Prototypes of the latter already appeared amongst Croatian finds and their spread might have taken place in the second half of the 9th century. These objects were 
successfully blending Christian iconography from earlier simple rings with elements of contemporary decorative arts, and the leading stylistic marks of the material culture of the elite. Their golden age fell to the 10th century and might have lasted until the end of the 11th century uninterrupted, however jewellery rings with similar content of meaning but with different ring forms and techniques of representation stayed in fashion. These items originally possessed religious meaning and their protective function must have contributed considerably to their popularity. This might also explain the fact that they are usually found in graves of females and children. Their genesis in a Christian environment does not necessarily imply that they were imported to the Carpathian basin because of the similarity in the mental background. Although the knowledge of the religious background cannot be entirely excluded in some cases, the general knowledge of their protective function might have contributed considerably to their relatively high number in the Carpathian Basin.

\section{Bracelets}

As it was already emphasised by B. Szőke the connections of the wire and twisted bracelets found in the graves of the Hungarian conquerors point to the direction of the Steppe, the region of the Northern fractional silver finds and to the Balkan periphery of Byzantium, just like in the case of other jewellery. ${ }^{15}$

Open bracelets made of simple wire are represented by five finds in the Carpathian Basin. Although many similar items were found in the catacombs of Mayak, ${ }^{16}$ it seems that Hungarians did not bring this jewellery type from the East, as it is nowhere to be found in the grave finds from the first half of the 10th century. Based on their physical appearance resembling open bracelets made of simple wire, the pair of bronze bracelets discovered at Baks was classified by researchers as one that originated from South Eastern Europe. ${ }^{17}$ Being decorated with small loops of wire make these items very peculiar in the material of the Hungarian conquest as this decoration was usually applied on ring jewellery. However, as no similar item is known hitherto from the Balkans or from Byzantium, it is still an open question whether this type really originated in the South. Especially as at the same time many parallels are known from Czech territory. ${ }^{18}$

Hinged bracelets were manufactured in Byzantium, but these objects are even rarer than the open bracelets made of simple wire. We know of only four examples altogether with the items of Szarvas and Tiszaeszlár datable to the 10th century and the finds from Ártánd to that of the 11th. A unique remain in the Carpathian basin is the open brand bracelet found in grave no. 77 of Hajdúszoboszló-Árkoshalom, which is simpler than the hinged bracelets. This type was also not developed in the 10th century, but as it is indicated by the cemetery excavated in Lesencetomaj - Piroskereszt, it appeared much earlier and stayed in fashion until the 12 th century. ${ }^{19}$

Bracelets of certainly South Eastern European origin were thus small in number and sparsely distributed in the Carpathian Basin. Their occurrence is minimal compared to the

15 SzŐKe 1962.

16 Винников - Афанасьев 1991.

17 SzÉlL 1942.

18 VeLímSKÝ 2007.

19 Yeroulanou 2010. 
simple wire bracelets, the open band bracelet with flaring terminal, or to the twisted bracelets. Some items, like the bracelets of Tiszaeszlár and Szarvas might have been obtained as booty, but the rest entered the Carpathian Basin as commercial items.

\section{Belt accessories}

At the moment we don't know any Byzantine belt mountings from the Carpathian Basin, only buckles. The buckles can only be verified as Byzantine if they have unique Byzantine related designs, and buckles like the one found in grave no. 115 in Somogy-Vasas being widespread not only in the Balkans but also in the Carpathian Basin, must be disregarded until further inquiry.

In my opinion it is hard to identify how and for what reasons rectangular buckles found in the Carpathian Basin were obtained by the conquerors, but they definitely relate to cultural contacts in the 10th century archaeological material. ${ }^{20}$ According to M. Schulze-Dörrlamm the diffusion of buckles was not based on personal contacts and they cannot be viewed as diplomatic gifts either. ${ }^{21}$ In all probability the central workshops were producing standardized buckle types according to the changing fashion, which then travelled via the commercial channels to faraway lands representing a kind of reflection of Byzantine fashion.

\section{Pendant crosses}

I studied simple hanging crosses after organizing them into ten subgroups. It was obvious that in some groups the function of crosses resembled those of the protective amulets, just like in the case of the Byzantine pendant found in grave no. 2 at Piliny-Leshegy with a Christian prayer engraved on it. Like in the case of the amulets, it is possible that many of the crosses were used as jewellery items, without a deep knowledge of their spiritual background or meaning. However a number of crosses might have been connected with Christian burials as their dating collides with the period when Christianization was well advanced and could have grown firm roots amongst wide circles of the population.

Even though wearing crosses was a common practice in Byzantine territories, its burial was not that widespread in Eastern Christian territories of the 10th century. In the Carpathian Basin I was unable to show a definite connection between the custom of burial with a cross and the relation of the community making the burial to Christianity. Thus it is at the moment impossible to prove with archaeological methods whether the person buried with a Byzantine cross was actually laid to final rest according to the Byzantine rites.

We are still unable to define the places where crosses were made neither by their makeup nor by their iconography. Their possible production into the Carpathian Basin is made unlikely by the fact that almost all items found hitherto are differing from each other. Thus there are no such clearly identifiable series that can be connected to peculiar workshops like the ones found in South Eastern Europe. ${ }^{22}$

20 LANGÓ - TÜRK 2004.

21 SCHUlze-DörRlamm 2009.

22 LANGÓ - TÜRK 2004; LANGÓ 2010a. 


\section{Conclusions}

The presence of Byzantine finds in the material culture of the early Hungarians cannot be solely explained by the Hungarian military expeditions directed against Byzantine territories and they cannot be regarded simply as the memento of former alliances or diplomatic contacts. Thinking about the movement of objects, one has to consider commercial contacts, the movement of the craftsmen or their technical knowledge.

The mapping of this multi-layered network of connections can be considerably enhanced by the analyses built on the classification of archaeological objects and the new data might enable us to place the objects into a wider context. Related objects and their parallels can help us to draw numerous historical conclusions as well.

Archaeological material connected to the various elements of attire contradicts previous assumptions concerning a long animosity between the conquering Hungarian tribes and the local Moravian population after the fall of the Moravian state. The local population integrated certain cultural elements of the Hungarians, while also enriching the culture of the newcomers. One example of this latter process was the transmission of the Byzantine influence in attire by the Moravians to the Hungarians. The archaeological remains thus testify the fast and peaceful integration of the two peoples. With regard to certain jewellery types it seems that direct Byzantine influence was rather sporadic or minimal on 10th century Hungarians. The presence of Byzantine influenced earrings in 9th century Moravian graves is much more characteristic than in the Carpathian Basin of the 10th century. In the 10th century this type of objects often appeared in the southern border regions, in Transdanubia and in Upper Hungary, all of which point to the fact that Byzantium had a much stronger influence on the region to the north of the Drava and Sava in the 9th century that it had in the 10th. The Transdanubian zone had a richer inheritance of Byzantine material from the 9th century which explains a somewhat stronger presence of these object in the 10th century. Besides, this territory always had very strong southern connections in previous periods as well, even though its culture was in many ways rather mosaic-like with a strong presence of large livestock breeding communities living beside settled ones with strong links to the South.

The culture that developed with the arrival of the Hungarians was different and in some ways it can be regarded more autonomous then the preceding Moravian culture. This is attested by the fact that contemporary Byzantine attire was able to leave traces only sporadically, and many of its objects so popular in other regions, (e.g. glass bracelets) were unable to make their appearance in the material culture. Earrings or rings are good indicators for the dynamics of diffusion of certain groups of objects (slow, in phases or fast) and the material analysed sheds some light on the dichotomy attested by the historical sources. Byzantine coins testify not only direct contacts, but also relate to the phases of the development of the connections. Although still leaving some uncertainties with regard to dating, this group of objects gives a fairly good picture on the middle range developments during the 10th century, if categorized and analysed according to the ratios. It reflects the growing importance that the Carpathian Basin acquired in the commercial processes and the development of its own commerce. Archaeological finds such as various types of earrings, decorated rings with widening bezel, cross pendants or Byzantine buckles all reflect processes similar to those of 
the coins. The loose and occasional nature of early relationships gave place to intensified and more complex contacts in the second third of the 10th century and it was considerably strengthened by the end of the century. This relationship also continued into the Árpádian age that is reflected in the 12th-13th century objects with South Eastern European contacts.

\section{References}

Albani, J. 2010: Elegance Over the Borders: The Evidence of Middle Byzantine Earrings. In: C. ENTwistle - N. Adams (ed.), Intelligible Beauty': Recent Research on Byzantine Jewellery. London, $193-202$.

Bosselmann-Ruickiıe, A. 2011: Byzantinischer Schmuck des 9. bis frühen 13. Fahrhunderts. Untersuchungen zum metallenen dekorativen Körperschmuck der mittelbyzantinischen Zeit anhand datierter Funde aus Bulgarien und Griechenland. Wiesbaden.

GÁLl, E. 2013: Az Erdélyi medence, a Partium és a Bánság 10-11. századi temetỏi, szórvány-és kincsleletei (10th and 11th Century Burial Sites, Stray Finds and Treasures in the Transylvanian Basin, the Partium and the Banat). Budapest - Szeged.

Григоров, В. 2007: Метални накити от средновековна България. София.

KEszi, T. 1999: 10. századi zárt lemezgyürűk pajzs alakúan kiszélesedő fejjel, pentagramma és madár ábrázolással (Geschlossene Plattenringe aus X. Jahhundert mit Schildförmig ausgebreitetem Kopf, mit Darstellung von Pentagramma und Vogel). In: Perémi, Á. (ed.), A népvándorláskor fiatal kutatóinak 8. találkozójának elóadásai. (Veszprém, 1997. november 28-30). Veszprém, 133-148.

Комар, А. В. 2006: Степи Европы в эпоху средневековья. 5: Хазарское время. Донецк.

KovÁcs, L. - VAdAy, A. 2012: Örménykút Site 52: Section of a Cemetery from the Period of the Hungarian Conquest. In: Vaday, A. H. - Jankovich B., D. - KovÁcs, L., Archaeological Investigations in County Békés 1986-1992. Varia Archaeologica Hungarica 25, 587-637.

KovÁcs, L. 2012: A magyar kalandozások zsákmányáról. Budapest.

LANGÓ, P. 2010a: Crescent-shaped Earrings with Lower Ornamental Band. In: DAIM, F. Drauschke, J. (Hrsg.), Byzanz - Das Römerreich im Mittelalter. Peripherie und Nachbarschaft. Mainz, 369-410.

LANGó, P. 2010b: A kora Árpád-kori temetők kutatása (Research into Cemeteries from the Early Árpádian Age). In: Benkő, E. - Kovács, Gy. (eds.), A középkor és a kora újkor régészete Magyarországon (Archaeology of the Middle Ages and the Early Modern Period in Hungary). Budapest, $445-469$.

LANGó, P. 2013: Notes on the dating of Byzantine coin finds from 10. th century context in the Carpathian Basin. In: ToBiAs, B. (Hrsg.), Die Archäologie der frühen Ungarn. Chronologie, Technologie und Methodik. Internationaler Workshop des Archäologischen Instituts der Ungarischen Akademie der Wissenschaften und des Römisch-Germanischen Zentralmuseums Mainz in Budapest am 4. und 5. Dezember 2009. Mainz, 49-66.

LANGÓ, P. - TÜRK, A. 2003: Honfoglalás kori női sír Szentes Derekegyházi oldal határrészéből. (Female Grave from the Conquest Period at Szentes, Derekegyházi oldal). Szentes.

LANGÓ, P. - TÜrk, A. 2004: Honfoglalás kori sírok Mindszent-Koszorús-dűlőn. Adatok a szíjbefúzős bizánci csatok és a délkelet-európai kapcsolatú egyszerű mellkeresztek tipológiájához (Landnahmezeitliche Gräber in Mindszent-Koszorús-dülő. Angaben zur Typologie der trapezförmigen 
byzantinischen Schnallen und einfachen Kreuzanhänger mit südosteuropäischen Beziehungen). Móra Ferenc Múzeum Évkönyve - Studia Archaeologica 10, 365-457.

Mesterházy, K. 1991: Bizánci és balkáni eredetű tárgyak a 10-11. századi magyar sírleletekben I. (Gegenstände byzantinischen Ursprungs in den ungarischen Gräberfeldern des 10.-11. Jh. I.). Folia Archaeologica 41, 87-115.

Mesterházy, K. 1992: Bizánci és balkáni eredetű tárgyak a 10-11. századi magyar sírleletekben II. (Gegenstände byzantinischen Ursprungs in den ungarischen Gräberfeldern des 10.-11 Jh. II.). Folia Archaeologica 42, 145-177.

Neuwirth, M. 1985: Hrob z mladší doby hradištní v Rudné okr. Praha-Západ (A female grave of the late bourgwall period at Rudná distr. of Práha-Západ). Archeologické rozhledy 37, 96-98.

ProнÁszka, P. 2012: Bemerkungen zum byzantinischen Münzverkehr der ungarischen Landnahmezeitund der Staatsgründung im Karpatenbecken. In: ToBIAs, B. (Hrsg.), Die Archäologie der frühen Ungarn. Chronologie, Technologie und Methodik. Internationaler Workshop des Archäologischen Instituts der Ungarischen Akademie der Wissenschaften und des Römisch-Germanischen Zentralmuseums Mainz in Budapest am 4. und 5. Dezember 2009. Mainz, 67-88.

RÉvÉsz, L. 1996: A karosi honfoglalás kori temetők. Adatok a Felső-Tisza-vidék X. századi történetéhez (Die Gräberfelder von Karos aus der Landnahmezeit. Archäologische Angaben zur Geschichte des Oberen Theißgebietes im 10. Jahrhundert). Magyarország honfoglalás kori és kora Árpád-kori sírleletei 1. Miskolc.

Ross, M. C. 1965: Catalogue of the byzantine and early mediaeval antiquities in the Dumbarton Oaks Collection. Dumbarton Oaks Catalogues. Washington.

Schulze-DörRlamm, M. 2009: Byzantinische Gürtelschnallen und Gürtelbeschläge im Römisch-Germanischen Zentralmuseum. Teil 2. Die Schnallen mit Scharnierbeschläg und die Schnallen mit angegossenem Riemendurchzug des 7. bis 10. Jahrhunderts. Kataloge Vor- und Frühgeschichtlicher Altertümer 30/2. Mainz.

SzÉLL, M. 1942: Elpusztult falvak, XI-XII. századbeli régészeti leletek Szentes határában. Dolgozatok a m. kir. Horthy Miklós Tudományegyetem Régiségtudományi Intézetéből 18, 128-132.

SzőkE, B. 1962: A honfoglaló és kora Árpád-kori magyarság régészeti emlékei. Régészeti Tanulmányok 1. Budapest.

Винников А. 3. - Афанасьев Г. Е. 1991: Культовые комплексы Маяцкого селища: (Материалы раскопок совет.-болг.-венг. экспедиции). Воронеж.

Yeroulanou, A. 2010: Important Bracelets in Early Christian and Byzantine Art. In: AdAms, N. (ed.), Intelligible Beauty. Recent Research on Byzantine fewellery. London, 40-49. 